\title{
MITI moves to open patents
}

\section{Tokyo}

FOREIGN companies that join research and development projects funded by Japan's Ministry of International Trade and Industry (MITI) should soon be able to hold patent rights arising out of the research. MITI hopes that the move will encourage foreign companies to take part in research and development projects in Japan.

Until now, all patent rights arising from projects funded directly by MITI have been held by the government, and participating
NEDO and MITI projects free of charge or for a "small fee". The powerful ministry has previously spurred Japan's economic success through aggressive national projects, and the patent legislation is seen as the first step in a new MITI policy of promoting international research on new technology among developed nations.

The new "technoglobalism" policy, which MITI announced at a meeting last year of the Organisation for Economic Cooperation and Development, is designed to counter
PATENT RIGHTS FOR COMPANIES PARTICIPATING IN GOVERNMENT-FUNDED RESEARCH AND DEVELOPMENT PROJECTS

\begin{tabular}{|c|c|c|}
\hline Country & Holder of rights & Licence fee \\
\hline \multicolumn{3}{|l|}{ Japan } \\
\hline National & Now: government & Fee required \\
\hline project & $\begin{array}{l}\text { Revised: } 50 \text { per cent or more } \\
\text { government; up to } 50 \text { per cent for } \\
\text { companies }\end{array}$ & Free or small fee \\
\hline $\begin{array}{l}\text { NEDO } \\
\text { project }\end{array}$ & $\begin{array}{ll}\text { Now: } & 50 \text { per cent or more NEDO; } \\
& \text { up to } 50 \text { per cent for companies }\end{array}$ & Fee required \\
\hline & Revised: as above & Free or small fee \\
\hline \multicolumn{3}{|l|}{ US } \\
\hline US companies & Companies & Free \\
\hline Non-US companies & Government & Free \\
\hline UK & Government & Free \\
\hline France & Companies & Free \\
\hline Germany & Companies & Free \\
\hline
\end{tabular}

companies - both foreign and Japanese have to pay licence fees to use technology arising from their own research. In the case of projects funded by the New Energy and Industrial Technology Development Organization (NEDO), a semi-government organization affiliated to MITI, companies can hold up to 50 per cent of patent rights, but they still have to pay licence fees.

Under a proposed new law, which MITI submitted last week to the cabinet, companies will have access to patents from

a perceived "technonationalism" in the United States, whereby the United States tries to protect its own technological advances from countries such as Japan that are making rapid progress in developing high technology.

The move to introduce the new legislation was in part spurred by a large-scale project launched by MITI through NEDO in 1989 to develop a "super/hypersonic transport system" to follow the Anglo-French Concorde. US and European companies, including INTERNATIONAL COLLABORATION \section{Euro-laser plans on ice}

London

EUROPEAN science administrators have shelved plans to build a laser facility that would compete with the best the United States and Japan have to offer. The proposed ten-year collaboration among Britain, Germany, France, Italy and Spain was aimed at producing a 100-kilojoule ultraviolet laser that would give European physicists a state-of-the-art machine with which to study plasma behaviour and the fusion of hydrogen isotopes (see Nature 346, 503; 1990). But Britain, France and Germany have now decided that the project is too expensive.

The British contribution is among the projects axed to ease the financial difficulties at the Science and Engineering Research Council (SERC, see Nature 349, 551; 14 February 1991), and the high costs of reunification are currently restricting
German spending on international science projects. The original proposal would have cost up to $£ 25$ million a year and would have required first building two smaller machines to test rival laser technologies before constructing the final $100-\mathrm{kJ}$ facility.

Michael Key, from SERC's Rutherford Appleton Laboratory and one of the authors of the European laser proposal, says the project may be revived when the economic situation across Europe improves. Key takes heart from the example of the European Synchrotron Radiation Facility, now being built in Grenoble, which was approved only after several years of discussion. In the short term, Key says the priority now is to upgrade existing lasers around Europe, and to encourage their shared use, perhaps through funding from the European Communities.

PeterAldhous
Rolls-Royce of the United Kingdom, United Technologies, Pratt and Whitney, and General Electric of the United States, and SNECMA of France, wanted to join the project, in which MITI will invest $¥ 28,000$ million (\$200 million) over eight years, but they were discouraged by the regulations governing patent rights. Agreement for these companies to join was finally reached a few weeks ago, after months of wrangling over patent rights.

The legislation will bring Japan more closely into line with France and Germany (see table). In the United States, foreign companies cannot hold patent rights arising out of government-funded research, but they can license technology free of charge if they participate in a project. In the United Kingdom, the government retains patent rights for inventions that arise from contract research, but companies can hold patents when the government only provides subsidies.

MITI official say they are optimistic that the Science and Technology Agency will soon follow suit with more general legislation covering all Japanese national research projects.

David Swinbanks

PREVENTIVE MEDICINE

\section{AIDS control through cultural heritage}

New Delhi

ANCIENT scriptures and religious books will be searched for messages that can be used to control the spread of AIDS in a new programme launched by the Indian Council of Medical Research (ICMR). The council says that Western-style educational campaigns, which often rely on television and printed booklets, will have little effect on Indians, whose life style is shaped more by religion than by science.

A. S. Paintal, director general of ICMR, notes that the United States and African countries have had difficulty controlling the spread of AIDS despite printed information and television advertisements. India has an advantage over Western countries in that it has a rich cultural heritage and scores of scriptures that already contain the necessary prescriptions for an AIDS-free society, Paintal says.

This led to the idea for the campaign, whose theme is "Protect yourself from AIDS through cultural heritage". The hope is that AIDS messages based on religion will be more easily accepted by an average Indian than the same messages given as bland scientific facts through health bulletins. Paintal says that Indian scriptures are replete with messages preaching moderation in sex and describing prostitution, homosexuality and adultery as sin. "All we are saying is, make our people aware of these teachings", Paintal says." Just telling them about safe sex will not help in changing their attitudes." K.S. Jayaraman 